\title{
Can religion (un)zombify? The trajectories of psychic capture theology in postcolonial South Africa
}

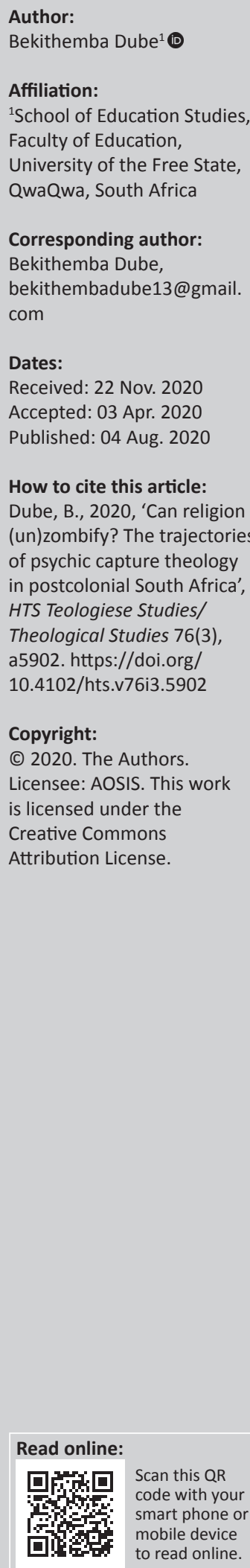

'Police arrested suspected criminals in a satanic place masquerading as a church ... There is no church there, but there is Satanism ... Those people are not praying for anything, but they have hypnotised abantu [people]'. Informed by a decoloniality lens in relation to motifs such as coloniality of power and knowledge and being, I argue that mafiarised religions in South Africa thrive through psychic capture theology. Some emerging religious movements subject their followers to unthinkable practices, which makes outsiders question the way in which both religious leaders and adherents operate outside the conventionally accepted practice of religion, and, instead, indulge in practices characterised by manipulation, corruption and mental destabilisation. I respond to two questions: What are the trajectories of a religion that zombifies, and how can the social pathologies of psychic capture theology be addressed? I respond to these questions with special reference to the Seven Angels Ministry and Penuel Mnguni. I argue that some emerging ministries strive to destroy the psychic ability of adherents, to achieve strategic distance that dehumanises, removes people from the zone of being, and causes them to question their ontological density. I end the article by arguing that there is a need for religion to be regulated, and reintroduced, to challenge religious mafias that thrive through mental destabilisation. In doing so, religion can be reconfigured and have relevance in a postcolonial state, such as South Africa, especially in contexts where the rationale of religious discourses is questionable.

Contribution: The article contributes to knowledge in the sense that it calls for religion to be problematised and reconstructed within education and sociological space when it dehumanise and removes people from the zone of being. Through this approach, the article fits with the scope for the journal that calls for interdisciplinary approach to the study within the international contexts.

Keywords: zombification; mental destabilisation; strategic distancing; decoloniality; ontological density.

\section{Introduction}

In most colonial states, religion evolved in ways that were, perhaps, never imagined or expected. In 'normal' circumstances, religion is assumed to facilitate social transformation, and promotes morality and social cohesion (Agbiji \& Swart 2015; Duncan 2001; Schnabel \& Groetsch 2014). Some researchers and prophets argue that a sincere faith in God is a necessary and uncontested condition for the individual's general well-being (Moskalets 2017). To this end, religion has often been associated with higher subjective well-being of individuals (Miu-Chi Lun \& Bond 2013). In addition, faith in God has been a 'vital factor for people's spiritual well-being and consequently, the strategic paradigm for all forms of psychological help' (Moskalets 2017).

However, Maluleke (1997:6) argues that the quest by Africans to articulate their own brands of theologies consciously, deliberately and, sometimes, carelessly, has evoked various trajectories and ambivalences, of which one is mental destabilisation. The reason for this is that, usually, when people visit churches or ministries, they hope to ensure a better future and find solutions for their social problems; however, in some cases, instead of problems being solved, people become entangled in exploitative acts that are easy to propagate through mental destabilisation. Mental destabilisation is partly as a result of religion has occupied a neo-liberal space, and resulted in misuse of the freedom of religion (Banda 2019; Henrico 2019; Magezi \& Banda 2017; Mashau \& Kgatle 2019). Considering the foregoing, it seems that some religious groups, especially in South Africa, thrive on mentally destabilising or incapacitating their adherents (Dayiman \& Ntshobane 2018).

Consequently, religion does 'not always significantly and positively relate to an individual's subjective well-being' (Eichhorn 2011; Leondari \& Gialamas 2009), especially when elements of criminality encroach on the religious space. 
As I begin this article, I am cognisant that my arguments may not be popular with some religious leaders, scholars and followers; however, the beauty of scholarship is that it allows a multiplicity of voices on the issue under discussion. I will show that decoloniality, as a theoretical lens informing this study, provides the impetus to disturb and challenge the status quo and evoke a new way of thinking that can reconfigure the practice of religion in society.

The article focuses on mental destabilisation as a direct or indirect product of mafia groups. Mafia, as used in this article, refers to religious groups that commit criminality in the name of religion; in some cases they are referred to as cultic groups (Ramabulana 2018). A mafia group does the opposite of what is conventionally accepted and expected of a religious group. So, for the purpose of this article, I use the term religious mafia loosely, to refer to criminality, cultic movements or any unconventional religious practices. Therefore, the purpose of problematising religious mafia in this article is to ignite a religion that restores us, together, as a community, so that the community can heal together (Gade 2012:493), to achieve social transformation and sustainable development. To this end, the article focuses on the religious groups that have soiled the beauty of what religion can offer society by perpetrating oppression and injustice, and resulting in zombification, which is manifested by mental destabilisation. Cognisant of this, I borrow a term from Wright, Zozula and Wilcox (2012:1) to describe the foregoing argument as a Christian failure narrative. This description is particularly valid, because some Christian practices are characterised by injustice and criminal elements.

\section{Locating the gap: Psychic capture theology}

This article's point of departure is the background that, in spite of various studies that have been conducted on the postcolonial religion in South Africa, none has focused on how religious tradition, praxis and discourses that are related to mafia groups have the impetus to destabilise adherents mentally. For example, Henrico (2019) conducted a study on contemporary prophets in South Africa and argues that the 'prophetic voice is an activity that addresses injustices in the society'. He concludes that:

[r]eligious freedom in South Africa is one of the few rights which has not been blighted with a history of either intervention on the part of the state or restrictions in terms of its expression. (p. 2)

Banda (2019) sought to investigate 'the recommendations of the Commission for the Promotion and Protection of the Rights of Cultural, Religious and Linguistic Communities (CRL Rights Commission) to regulate religion in South Africa'. The article ends by identifying the dangers of the recommendation of the CRL Rights Commission that religion should be regulated in South Africa. Recent research conducted by Dubarry and Muller (2019) discusses Pentecostalism and its relationship with the secular. They explain how Pentecostalism, in contrast to traditional forms of Christianity, is, par excellence, involved in the immanent and horizontal affairs of believers' lives. However, they did not focus on the negative aspects of religion, which this article designates as the religious mafia. I pay particular attention to mental destabilisation as a by-product of some religious praxis.

\section{Theoretical framing: Decoloniality}

This article is couched in decoloniality. Decoloniality theory, in its broader perspective, involves 'a commitment to challenge and reformulate the communicational scientific discourse, from a criticism of the mediating power of AngloAmerican hegemonic thinking, to a native cultural paradigm' (Huerfano, Caballero \& Rojas 2016:78). Among its primary mandates or objectives is to work 'toward a vision of human life that is not dependent upon or structured by the forced imposition of one ideal of society over those that differ' (Mignolo 2007:22), especially in cases where mental destabilisation occurs through religion. To this end, the 'theory questions the legitimacy and sanity of celebrating postcolonial thinking while the majority of Africans remain mentally colonized' (Kaunda 2015:77). I see this theory as relevant for this article because it engages in a struggle against the Euro-North American global design strategy, which is visible in religion that is informed by binarism and hierarchisation, and which keeps power imbalances and the colonial legacy intact (Sithole 2014). To promote the agenda of decoloniality, the theory makes reference to three motifs, which are coloniality of power, knowledge and being. These 'three concepts enable a deeper understanding of the construction of the current modern world that is today besieged by a plethora of crises' (Ndlovu-Gatsheni 2013).

I believe it is important to define the relationship between decoloniality and coloniality before I discuss the motifs further. The concept of coloniality was first introduced around 2000 by Anibal Quijano (2000) and Walter Mignolo (2007). Maldonado-Torres (2011) argues that:

[c]oloniality survives on colonialism. It is maintained alive in books, in the criteria for academic performance, in cultural patterns, in common sense, in the self-image of peoples, in aspirations of self, and so many other aspects of our modern experience. In a way, as modern subjects we all breathe coloniality all the time and every day. (p. 2)

The continuity of the colonial discourse in the 'post-apartheid South Africa, however, calls for a decoloniality project' (Ndlovu-Gatsheni 2013:10). Thus, as I use the term coloniality in this article to understand how some religious groups undervalue and dehumanise the imagination and the mind of religious followers (Seroto 2018). Coloniality of power is a useful concept that:

[d]elves deeper into the roots of the present asymmetrical global power relations and how the present modern world order was constituted. It boldly enables a correct naming of the current 'global political present' as a racially hierarchized, EuroAmerican-centric, Christian-centric, patriarchal, sexist, capitalist, hetero-normative, hegemonic, and modern power structure (Ndlovu-Gatsheni 2013). (p. 10) 
The 'coloniality of knowledge poses epistemological questions that are linked to, (1) the politics of knowledge generation; (2) questions of who generates which knowledge and for what purpose; (3) the question of relevance and irrelevance of knowledge; and (4) how some knowledges disempowers/empowers communities and peoples' (Ake 1979, cited by Ndlovu-Gatsheni 2013:10). Coloniality of being is defined by Maldonado-Torres (2011:2) as the combination of coloniality of power and coloniality of knowledge. Furthermore, 'coloniality of being is that of racial invention where the notion of race and nationality is used as the organising principle through the combination of power and knowledge' (Sithole 2014:44). I conclude by buttressing Ndlovu-Gatsheni's (2013:177-195) observation that schools, colleges, universities and religious groups in Africa are sites for the reproduction of every kind of coloniality. Therefore, decoloniality scholars should continue to engage in a struggle to unmute, tease and challenge coloniality, and I do so in this article with reference to religious movements that destabilise some people's mental capacities. In the following section, I will expand on psychic capture, with reference to the Seven Angels Ministry and Penuel Mnguni.

\section{Seven Angels Ministry, mental incapacitation and mafia tendencies}

The Seven Angels Ministry is a religious organisation that has contributed to the question of the relevance of religion in society, especially because of its approach to the praxis of religion. This ministry was located in the South African province of the Eastern Cape, in a small town, Ngcobo. After the death of their father in 2015, the church was led by Banele Mancoba and six other Mancoba brothers: Xolisa, Thandazile, Philile, Phuthumile, Benjamin and Ephraim (Singh 2018). The seven brothers referred to themselves as angels, which was, of course, the start of signs of mental destabilisation that was, in turn, transferred to ministry members, as will be discussed shortly. To show mental instability among the Seven Angels, I cite an interview with the SABC (2016:online):

We are saying as Seven Angelic Ministries, firstly I am not a pastor; I am an angel from heaven, seated at the right of the Father. We say that children should not go to schools because the devil has intervened with the schools. We will continue to tell the learners to stop going to school and not to listen to the constitution because the devil has taken over the schools.

In this statement, I notice three problematic issues regarding the Seven Angels Ministry. Firstly, they do not see themselves as human beings. By this statement, they are claiming that they are not in the zone of being, which makes them superior to other human beings, thus facilitating exploitation of vulnerable members of society. So, if their starting point is that they are 'more' than human beings, it follows that all their adherents must treat them as such, which opens the door for mutual zombification in relation to religious narratives (Dube 2019). Secondly, they forbid children to exercise their basic human right of access to education. When children are denied education based on religious discourses, and parents and guardians agree to such prescriptions, it presents issues of mental destabilisation for the children, parents and religious leaders. As long ago as 1991, Chidester referred to denying learners education as 'Saving children by killing them', a dangerous philosophy that still engulfs mafia religious groups. In light of these claims, I argue that decoloniality is a theory that works to change circumstances for the better, especially in contexts where people have experienced dehumanisation. No doubt, when children are exposed to such thinking and doctrine as that of Seven Angels Ministry, there is a need for steps to be taken to assist children, in particular. The third matter I notice is that the Seven Angels Ministry disregards the Constitution of South Africa - they consider it to be evil. SABC (2016:online) reports on and elaborates the Seven Angels Ministry's thinking with regard to the Constitution as follows:

There is an angel that left heaven by the name of Lucifer whom we have come to seek on earth. He has come and has breathed into the constitution of South Africa and its schools. He took schools and the constitution to himself ... we also say that the people must not listen to the constitution because it is controlled by the devil. (SABC 2016:online)

When religions enter a space where they undermine the constitution, then such religions should be treated as national threats, which act contrary to Romans 13, which exhorts people to be loyal to governments, not only for political reasons, but also for reasons relating to the mental health of those who follow such beliefs. Decoloniality, as the lens informing this study, opposes informed imposition of ideas, especially ideas that dehumanise. When religious groups destabilise people's mentality, it requires outsiders to engage with insiders through challenging them and questioning the legitimacy of ideas that operate beyond the boundaries of what is considered normal, acceptable and desirable in a democratic space like that of South Africa. However, I acknowledge that this is not an easy task, although it is possible and desirable. The difficulty is that religious groups like the Seven Angels Ministry enforce strategic distancing (Chidester 2003). This is an act that separates religious followers from the rest of the world, such as family, media, health care and schooling. Through this separation, religious adherents are made to believe that everyone else is evil and does not seek their good - it is only church leaders and religious fellows who can assist them. Under such circumstances, mental destabilisation takes place and mutual zombification becomes the order of the day (Mbembe 2002). It appears that the Seven Angels, in addition to declaring themselves angels, are actual religious mafia, whose behaviour affected many people, to the extent of causing psychological damage, material loss and loss of innocent lives. An example of the latter, which occurred at a police station, is reported by Evans (2018). To this end, the brothers colonised religious knowledge about God in order to commit mafia acts. Thus, I problematise this matter with a decoloniality lens, because a society cannot be sustained with an approach that isolates members from the realities - history teaches us that such religious groups end in catastrophe, as exemplified by the People's Temple, where 914 people died after being poisoned by their religious leader, Jim Jones, after 
being excluded from the entire community (Chidester 2003; Sanua 2007; VanDeCar 2003). Another example is Hopeful Christian of the Gloriavale Christian Community, where people were isolated to Haupiri valley and were exposed to sexual harassment by their leader, Neville Cooper (Tarawa 2017). Further examples are Jim Bakker, of a Christian compound deep in the Ozark Mountains of Missouri, who used his popularity to commit 24 accounts of fraud, tax inversion and conspiracy (Funk 2018) and Gilbert Deya, who promised infertile women they could have 'miracle babies' and was involved in stealing babies which were presented to infertile women to confirm 'miracle babies' (BBC News 2017). The list seems endless. Acts by Seven Angels Ministry are evidence of a trajectory of our time that needs to be challenged from every space, including a scholarly one.

Part of the trajectory is that religious members often believe that leaders are right, and any criticism of these leaders is a direct attack by evil. Gregg (2016) elaborates:

Often, members believe that their [leaders'] views are absolute and right, and a direct revelation from God, which is also one of the characteristics of fundamentalist religious groups. Under these auspices, the adherents of a religious mafia become extremist, characterised by resistance to the political practices of the day. (p. 346)

Cognisant of Gregg's observation, scholars who value social justice need to confront a considerable challenge, which is to usher in a religion devoid of exploitation and dehumanisation. In another trajectory, in addition to mental destabilisation with the aim of committing criminal acts through religion, the Ngcobo 'angels' plundered people's resources, especially those of pensioners. They expressed deceitful narratives that persuaded people to give up their lives and resources. I argue that coloniality of power dehumanises, and that cheating is prevalent in most mafia religious groups. Herman (2018) reports that, at Ngcobo Seven Angels Ministry, pensioners in the church gave all they had (cars and money) to the church and were left penniless, while the brothers drove convertible cars at the expense of the ministry members. Herman (2018) cites Thoko Mkwananzi Xulusa, the former commissioner of the CRL Rights Commission, on this matter:

At that point in the church, no one was working, but they were buying expensive cars like that. It means they were spending beyond the norm. The proof was in me asking them how many cars they had. They responded: 'We don't know, you'll have to come and count them yourself. We have lots of cars'. (p. 1)

Informed by these reports, I conclude that religious groups with mafia tendencies strive, through mental destabilisation, to cheat congregants by capitalist tendencies, characterised by excessive commercialisation of the sacred, and commodification of grace, prayer and offering (Methula 2017:4). I argue that most mafia religious movements in postcolonial South Africa practise a psychic capture theology, a theology that destabilises religious adherents, which makes exploitation inevitable and ultimately becomes destructive.

In the following section, I will refer to the trajectories of psychic capture theology as exemplified by Penuel Mnguni.
I will explain the mental destabilisation construct further and critique it within decoloniality thinking.

\section{Penuel Mnguni, eating snakes and controlling minds}

Little was known about Penuel Mnguni, a pastor at Ambassadors of Christ Gospel Ministries church in Polokwane (eNCA 2019), until his questionable practices became public, which led to people questioning him and his religious group, especially in relation to mental destabilisation. His actions have led the South African Council of Churches to approach the:

Human Rights Commission (HRC) to investigate Penuel Mnguni, a controversial Soshanguve pastor who fed his congregants rodents, snakes and other objects. The Council believed his actions brought the name of Christianity into disrepute. (Bendile 2015:1)

With reference to Mnguni, I will investigate three issues that made headlines, that is, eating snakes, driving over congregants, and using dog meat for Holy Communion. Surprisingly, religious adherents complied with the directives, which leads to my conclusion that, when people believe that eating dog food and snakes is an act of holiness, and do it, then the psyche has been captured. These people have been dehumanised and are unable to identify or challenge oppression through religion. They have become helpless and removed from the zone of being and have become mere zombies. However, I also acknowledge that my submission can be seen as unorthodox, especially by people within mafia religions who practice psychic capture. The mafia works through coloniality of knowledge, and the views of anyone who objects are considered undesirable and a threat. Mnguni's coloniality of knowledge gives him the ability to capture people's psyches. Citizen Reporter (2018) reports Mnguni saying that using "'biscuits and juice" for Holy Communion were old hat and that anything could be used to give glory to God'. So, the captured psyche cannot see, name and challenge praxis and narratives that seem out of the ordinary. A congregant elaborated, when asked about Mnguni driving his car over them as a healing process, as reported by Mitchley and Schatz (2018):

The man of God then commanded them to wake up while the car was on top of their bodies. He then asked them if they felt any pain and their response was 'we do not feel anything'. (p. 1)

On the basis of the foregoing discussion, I agree with Damiani (2002:45), that psychic capture theology 'destroy[s] any individual's personality and replaces the void with a cultic personality that no longer questions, thinks critically, or feels the impact of an abusive system'.

Therefore, it is clear that the psyche has been captured, and harmful acts are exposed to religious followers.

Once a society succumbs to a religious mafia, it is doomed, and it requires an intervention from outsiders who can name, problematise and challenge acts that are harmful to the 
members of that society. To this end, I support Mpofu (2017), who argues that there is a need for a counter-hegemonic strategy that can evoke a philosophy of liberation, which entails the rehumanisation of the dehumanised and the courage to care and to love, while at the same time challenging forces that capture people's psyches under the pretext of religious obedience to the man of God. In the following section, I will suggest ways in which psychic capture theology and zombification can be mitigated in society.

\section{What can be done? Towards a non- capturing religion in South Africa}

In the previous section, I outlined the challenges related to psychic capture theology, which has dehumanised and pushed vulnerable members of society out of the zone of being. It is, thus, important that scholars who attach value to social justice, equity and decoloniality declare war on all forms of coloniality that threaten the beauty of religion in society. I argue that there is a need for a religion that not only consoles, but which provokes people to think through religious practices (McConaghy 2003:11), to expose and challenge injustice, which, in this case, manifests through mental destabilisation. I suggest two solutions as an attempt to redress the challenge. These are regulation of religious practice, and reintroduction of religion in mainstream curriculum practice. The goal of these suggestions is expounded by Alvesson (1992):

Individuals and groups become freed from suppressive social and ideological situations, particularly those that place socially unnecessary precincts upon development and enunciation of human consciousness and consequently people acquire and exercise power over their thought processes, life-worlds to change oppressive conditions. (p. 432)

\section{Regulating religion in South Africa}

In this section, I will commence by admitting that, in democratic, pluralistic and secular societies, freedom of religion is a fundamental right, to be enjoyed by all individuals and religious organisations (Henrico 2019).

Because of this right, many scholars reject the regulation of religion, and describe it as undemocratic and infringing on people's rights. Such resistance results mainly from the recommendation by the CRL Rights Commission (2015) that religious practices, like practices of any other professional bodies, must be regulated.

The recommendation was made because of concern that some religious groups have practices that have become a national threat. Dube (2019) advocates for regulation because certain practices by religious movements pose a threat to the state and community at large. However, Henrico (2019) sees the CRL Rights Commission proposal as unduly restricting and limiting the people's right to religious freedom, while Freedom of Religion South Africa (2017) sees it as unnecessary, unworkable and unconstitutional. Coertzen (2017) is also against the regulation of religion and argues that it is unconstitutional, wrong, and a serious offence against freedom of religion. Scholars and organisations are entitled to resist regulation; however, despite the negative aspects associated with the regulation of religion, I agree with the view that

[ $t$ ] here is a need for an immediate redress by the State or Religious organisations on the infringement of human rights by religious institutions and for accountability on the part of Pentecostal/Charismatic orientated churches in addressing practices that relate to the issues of human rights and human dignity. (Mokhoathi \& Rembe 2018:4)

In my view, regulation does not mean interfering with what the religion is doing on a day-to-day basis, but it requires a degree of accountability, whether to the state or other religious bodies, as a means to provide support in promoting the agenda of social justice and human rights. It cannot be permitted that some religious groups commit criminality, exercise mafia tendencies and hide under the pretext of religious freedom. Regulation of religion is not intended to destroy the autonomy of the church or religious groups but is an attempt to assist to curb criminality and, in particular, psychic capture. It is intended as a check and balance to protect citizens from individuals and religious institutes who use their power and influence to exploit the vulnerable members of society. It does not seek to hinder religious freedom but to ensure that citizens, especially children and women, are protected and that the rights of social justice and respect remain core both in praxis and discourses. Religious actors who value social justice must be part of the regulatory body, not for punitive measures, but to assist the state to name, identify and challenge praxis that is out of the ordinary of what is expected of a religion in society. My submission is that, as long as religious leaders resist regulation, South Africa will always face challenges related to religious abuse, since criminals and psychopaths will always see religion as an avenue to commit various crimes and hide under the banner of religious freedom, as a result of its lack of regulation. Thus, informed by decoloniality thinking, the goal of regulating religion is not to enforce punishment for exercising religious rights, but to serve as a guide to eliminate abuse and avoid dehumanisation, thereby reinventing a new order, system and life that is devoid of the coloniality that manifests as psychic capture theology.

\section{Reintroducing religion in schools}

In addition to regulating religion, I suggest that there is a need to reintroduce religious education in mainstream curriculum practice. I admit that with the current curriculum arrangement in South Africa, the teaching of religion is fast losing ground, especially as a result of the recommendation that life orientation (which had a very limited religious component) be eliminated at the Further Education and Training level (Khubeka 2018).

With this in mind, Bernstein (1970:47) states that the way in which a society selects, clarifies, distributes, transmits 
and evaluates the educational knowledge it considers public reflects both the distribution of power and the principle of social control. Thus, when few individuals are privy to religious knowledge, there is likely to be abuse for personal gain, creating coloniality of knowledge. This coloniality of knowledge has not only deprived learners and society of the opportunity to learn religion from a neutral perspective, but has also contributed to mental destabilisation, which is an easy avenue for capturing minds and, consequently, promoting an abuse agenda under the pretext of religion. I believe that equipping learners with religious knowledge will assist them to confront the challenges presented by religion from a critical space. This is my belief, because decoloniality argues that religious people have to participate in their own liberation from oppressive leaders. This is possible when learners engage in religious praxis in a critical and reflective manner, with the goal of promoting justice and human rights (Dube, Nkoane \& Hlalele 2017). Since all people are religious or spiritual in one way or the other, it is important that the school system contributes to cultivating religious knowledge, not only for personal growth and decisionmaking, but also to arm learners, so that they can confront criminality and mafias that have found a comfort zone in the space presented by religious freedom. I submit that religion, as taught at school, can assist to eliminate the zombification that is the trajectory of some postcolonial religious movements.

\section{Conclusion}

In this article, I explained how some religious movements are based on a psychic capture theology that works through mental destabilisation. I developed this argument by investigating the Seven Angels Ministry and Penuel Mnguni. I argued that religion is becoming a problematic phenomenon in society owing to some people using freedom of religion as a safe haven to act in criminal ways. I conclude the article by arguing that regulation, even though it is opposed by many, is important to counter this trend. This regulation should not be enforced by the state only; instead, religious leaders should assist to regulate cases where it is evident and clear that religion is being used to commit crimes. I also conclude that reintroducing religious education in the mainstream curriculum should be considered, to arm learners with knowledge to challenge all forms of coloniality that dehumanises, removes religious adherents from the zone of being, and reduces their ontological density.

\section{Acknowledgements Competing interests}

The author has declared that no competing interest exists.

\section{Author's contributions}

I declare that I am the sole author of this research article.

\section{Ethical consideration}

This article followed all ethical standards for a research without direct contact with human or animal subjects.

\section{Funding information}

This research received no specific grant from any funding agency in the public, commercial or not-for-profit sectors.

\section{Data availability statement}

Data sharing is not applicable to this article as no new data were created or analysed in this study.

\section{Disclaimer}

The views and opinions expressed in this article are those of the authors and do not necessarily reflect the official policy or position of any affiliated agency of the authors.

\section{References}

Agbiji, O.M \& Swart, I., 2015, 'Religion and social transformation in Africa: A critical and appreciative perspective', Scriptura 114, 1-20, viewed 27 March 2020, from http://www.scielo.org.za/scielo.php?script=sci_arttext\&pid=S2305-445X20150 00100010\&lng=en\&tlng=en.

Ake, C., 1979, Social Science as Imperialism: The Theory of Political Development, Ibadan University Press, Ibadan.

Alvesson, M., 1992, 'On the idea of emancipation in management and organization studies', The Academy of Management Review 17(3), 434-454. https://doi. org/10.2307/258718

Banda, C., 2019, 'Redefining religion? A critical Christian reflection on CRL Rights Commission's proposal to regulate religion in South Africa', Verbum et Ecclesia 40(1). https://doi.org/10.4102/ve.v40i1.1948

BBC News, 2017, 'Gilbert Deya: "Miracle babies" pastor extradited to Kenya', BBC News, 04 August, viewed 12 September 2019, from https://www.bbc.com/news/worldafrica-40824267.

Bendile, D., 2015, 'HRC asked to investigate "snake pastor"', Eyewitness News, 08 November, viewed 22 September 2019, from https://ewn.co.za/2015/08/11/HRCasked-to-investigate-snake-pastor.

Bernstein, B., 1970, Coding and framing in education, Routledge, London.

Chidester, D., 1991, 'Saving the children by killing them. Redemptive sacrifice in the ideology of Jim Jones and Ronald Reagan', Religion and American Culture. A Journal of Interpretation 1(2), 177-201, https://doi.org/10.1525/rac.1991.1.2.03a00030

Chidester, D., 2003, Salvation and suicide: Jim Jones, the Peoples' Temple, and Jonestown, Indiana University Press, Bloomington, IN.

Citizen Reporter, 2018, "'Snake pastor" now feeding the faithful frogs, worms and tentacled things', The Citizen 14 October, viewed 12 October 2019, from https:// citizen.co.za/news/south-africa/2022542/snake-pastor-now-feeding-the-faithfulfrogs-worms-and-tentacled-things/.

Coertzen, P., 2017, Freedom of religion: To have and to protect religious rights and freedoms, Paper, Stellenbosch University, Stellenbosch.

CRL Rights Commission, 2015, CRL Rights Commission's preliminary report of the hearings on commercialisation of religion and abuse of people's belief systems, viewed 20 October 2019, from http://www.crlcommission.org.za/docs/Preliminary\% 20 Report $\% 20$ of $\% 20$ the $\% 20$ hearings $\% 20$ on $\% 20$ Commercialization $\% 20$ of $\% 20$ Religion.pdf.

Damiani, R., 2002, 'Spiritual abuse within the church. Its damage and recovery process', Evangel 20(2), 42-48.

Dayiman, M. \& Ntshobane, S., 2018, “'We didn't know," say Ngcobo church followers', Sowetanlive 26 February, viewed 13 March 2018, from www.sowetanlive.co.za/ news/southafrica/2018-02-26-we-didnt-know-say-church-followers/.

Dubarry, T. \& Muller, R., 2019, 'Pentecostal churches and capitalism in a South African township: Towards a communism of the market?', Journal of Religion in Africa. https://doi.org/10.13140/RG.2.2.24583.55202

Dube, B., 2019, 'Conundrum of religious mafia and legislation in South Africa: When does religion become a national threat? Reference to the Seven Angels Ministry', Verbum et Ecclesia 40(1), a1864. https://doi.org/10.4102/ve. v40i1.1864

Dube, B., Nkoane, M.M. \& Hlalele, D.J., 2017, 'Ambivalence of freedom of religion and unearthing the unlearnt lessons of religious freedom from the Jonestown incident. A decoloniality approach', Journal for the Study of Religion 30(2), 319-338, viewed 16 October 2019, from http://www.scielo.org.za/scielo. 319-338, viewed 16 October 2019, from http://wW
php?scipt=sci_arttext\&pid=S1011-76012017000200015. 
Duncan, G.A., 2001, 'The role and function of traditional leadership and its institutions: A reflection on ethnic-cultural identity, African religion and customs for moral renewal and social transformation', Verbum et Ecclessia 23(2), 333-343. https:// doi.org/10.4102/ve.v23i2.1198

Eichhorn, J., 2011, 'Happiness for believers? Contextualizing the effects of religiosity on life-satisfaction', European Sociological Review 28, 583-593. https://doi. org/10.1093/esr/jcr027

eNCA, 2019, 'Self-proclaimed pastor serves "dog meat" as Holy Communion' eNCAnews, 22 May, viewed 01 September 2019, from https://www.enca.com/ news/self-proclaimed-pastor-serves-dog-meat-holy-communion.

Evans, J., 2018, 'Ngcobo massacre: Mbalula brands shoot-out church "satanic", News24, 24 February, viewed 01 March 2018, from www.news24.com/ southafrica/news/ngcobo-massacre-mbalula-brands-shoot-out-churchsatanic-20180224.

Freedom of Religion South Africa, 2017, Open letter to the CRL rights commission on its final report on the commercialisation of religion and abuse of people's belief systems, 16 May, viewed 07 October 2019, from https://forsa.org.za/open-letterto-the-crl-rights-commission-on-its-final-report-on-the-commercialisation-ofreligion-and-abuse-of-peoples-belief-systems/.

Funk, T., 2018, 'Fallen PTL preacher Jim Bakker is back with a new message about the apocalypse', Charlotte Observer, 19 February, viewed 12 October 2019, from https://www.charlotteobserver.com/living/religion/article200297074.html.

Gade, A.M., 2012, 'Traditional sentiment in Indonesian environmental Islam', World Views: Global Religions, Culture and Ecology 16(3), 263-285. https://doi. org/10.1163/15685357-01603005

Gregg, H.S., 2016, 'Three theories of religious activism and violence: Socia movements, fundamentalists, and apocalyptic warriors', Terrorism and Political Violence 28(2016), 338-360. https://doi.org/10.1080/09546553.2014.918879

Henrico, R., 2019, 'Proselytising the regulation of religious bodies in South Africa: Suppressing religious freedom?' Potchefsroom Electronic Law Journal 22(2019), 1-27. https://doi.org/10.17159/1727-3781/2019/v22i0a5315

Herman, O., 2018, "'You couldn't count the cars" - CRL on Ngcobo ministry's opulence', News24, 20 March, viewed 20 May 2018, from www.southafrica/ news/you-couldnt-count-the-cars-crl-on-ngcobo-ministry-opulence.

Huerfano, M., Caballero, B.J. \& Rojas, F.S., 2016, Towards an epistemology of the South. Decoloniality, informative knowledge power and the new Latin-American community, Latioamerican de Comunicacion, Chasqui.

Kaunda, C.J., 2015, 'The denial of African agency: A decolonial theological turn', Black Theology 13(1), 73-92. https://doi.org/10.1179/1476994815Z.00000000048

Kgatle, M., 2018, 'The prophetic voice of the South African Council of Churches: A weak voice in post-1994 South Africa', HTS Teologiese Studies/Theological Studies 74(1), a5153. https://doi.org/10.4102/hts.v74i1.5153

Khubeka, T., 2018, Task team recommendation history be made compulsory at schools from 2013, viewed 03 September 2019, from www.ewn.co.za/2018/05/31taskteamrecommends-hitsory-be-made-compulsory-at-schools-from-2023.

Leondari, A. \& Gialamas, V., 2009, 'Religiosity and psychological wellbeing' International Journal of Psychology 44, 241-248. https://doi.org/10.1080/ International Journal

Magezi, V. \& Banda, C., 2017, 'Competing with Christ? A critical Christological analysis of the reliance on Pentecostal prophets in Zimbabwe', In die Skriflig 51(2), 1-8. https://doi.org/10.4102/ids.v51i2.2273

Maldonado-Torres, N., 2011, 'Thinking the colonial turn. Post-continental interventions in theory, philosophy, and critique. An introduction', Transmodernity 2011(fall), 1-14.

Maluleke, T.S., 1997, 'In search of "the true character of African Christian identity". Review of the theology of Kwame Bediako', Missionalia 25(2), 210-219.

Mashau, T. \& Kgatle, M., 2019, 'Prosperity gospel and the culture of greed in postcolonial Africa: Constructing an alternative African Christian theology of Ubuntu', Verbum et Ecclesia 40(1), a1901. https://doi.org/10.4102/ve.v40i1.1901

Mbembe, A., 2002, 'African modes of self writing', Public Culture 14(1), 239-273. https://doi.org/10.1215/08992363-14-1-239
McConaghy, C., 2003, Curriculum and accountability in an age of trauma, Paper presented to the Annual Meeting of the American Educational Research Association, Chicago, IL.

Methula, D.W., 2017, 'Decolonising the commercialisation of the university and theological education in South Africa', HTS Theological Studies 73(3), 1-7. https:// doi.org/10.4102/hts.v73i3.4585

Mignolo, W., 2007, 'Delinking', Cultural Studies 21, 449-514. https://doi.org/ $10.1080 / 0950238060116264$

Mitchley, A. \& Schatz, C., 2018, “'Snake pastor" feeds dog meat to congregants for communion, News24, 16 October, viewed 12 September 2019, from https://www. news24.com/SouthAfrica/News/snake-pastor-feeds-dog-meat-to-congregantsfor-communion-20181016.

Miu-Chi Lunn, V. \& Bond, M.H., 2013, 'Examining the relation of religion and spirituality to subjective well-being across national cultures', Psychology of Religion and Spirituality 5(4), 304-315. https://doi.org/10.1037/a0033641

Mokhoathi, J. \& Rembe, N.S., 2018, 'Religious liberties and the constitution of South Africa: A call for religious accountability', Scriptura 116(1), 1-10.

Moskalets, V., 2017, 'Faith in God as a psychic factor in the individual's spiritual wellbeing', Journal of Vasyl Stefanyk 4(2), 79-87. https://doi.org/10.15330/ jpnu.4.2.79-87

Mpofu, W., 2017, 'Decoloniality as travelling theory: Or what decoloniality is not', Wits Institute for Social and Economic Research Seminar, 07 August 2017, University of the Witwatersrand, Johannesburg.

Ndlovu-Gatsheni, S.J., 2013, 'Why decoloniality in the 21st century?', The Thinker for Thought Leaders 48(2013), 10-16.

Quijano, A., 2000, 'Coloniality of power and social classification', Journal of World Systems 6(2), 342-386. https://doi.org/10.5195/jwsr.2000.228

Ramabulana, M.F., 2018, Church mafia. Captured by secret powers. An untold African narrative, Makhado Sinthumule Ramabulana, eBook, Kindle Store.

SABC (South African Broadcasting Corporation), 2016, 'Angels Ministries, E Cape swears to defy constitution', SABC Digital News, 01 March, viewed 23 March 2018, from https://www.youtube.com/watch?v=qxWPLgA-XrQ.

Sanua, M.R., 2007, Let us prove strong. The American Jewish Committee 1945-2006, Brandeis University Press, Waltham.

Schnabel, A. \& Groetsch, F., 2014, 'In God wetrust - The role of religion for cohesion and integration in current Europeansocieties', European Journal of Cultural and Political Sociology 1(4), 375-398. https://doi.org/10.1080/23254 823.2015.1057752

Seroto, J., 2018, 'Dynamics of decoloniality in South Africa: A critique of the history of Swiss mission education for indigenous people', Studia Historiae Ecclesiasticae 44(3), 1-14. https://doi.org/10.25159/2412-4265/3268

Singh, K., 2018, 'Seven Angels Ministry leader appears in court, News24, 05 May, viewed 24 September 2019, from https://www.news24.com/SouthAfrica/News/ seven-angels-ministry-leader-appears-in-court-20180507.

Sithole, T., 2014, 'Achille Mbembe: Subject, subjection, and subjectivity', Unpublished $\mathrm{PhD}$ thesis, University of South Africa, Pretoria.

Tarawa, L., 2017, 'My life in a religious cult: "The most dangerous place in the world is the womb of an ungodly woman', The Guardian, 29 August, viewed 11 October 2019, from https://www.theguardian.com/books/2017/aug/30/my-life-in-areligious-cult-the-most-dangerous-place-in-the-world-is-the-womb-of-anungodly-woman.

VanDeCar, P., 2003, 'The Jonestown that won't fade away. Twenty-five years later: A filmmaker examines the lasting consequences', Harvard Divinity Bulletin, Fall, 24-25, viewed 11 September, 2019 from http://web.math.ucsb.edu/ mgscharl/ 24-25, viewed

Wright, B.R., Zozula, C. \& Wilcox, W.B., 2012, 'Bad news about the good news: the construction of the Christian-failure narrative', The Aquila Report, 30 December, viewed 11 September 2019, from https://www.theaquilareport.com/bad-newsabout-the-good-news-the-construction-of-the-christian-failure-narrative/. 